\title{
An Approach to Enhance Biomethanation by Thermophilic Aerobic Digestion of Combined Vegetable Waste.
}

\author{
Ashwini J. Kamble ${ }^{1}$, M.G.Takwale ${ }^{2}$, V.S.Ghole ${ }^{3}$ \\ ${ }^{1}$ (University of Pune, India) \\ ${ }^{2}$ (Ex. V.C. Shivaji University, India) \\ 3 (National Institute of Virology, India)
}

\begin{abstract}
In biogas volatile fatty acid are the principle source of energy for methanogens and an increase in their concentration can enhance the process performance of biogas digester. A two phase anaerobic digestion system was used to study the effect of various factors on the net production of volatile fatty acid (VFA). For this purpose thermophilic digester maintained at $55^{\circ} \mathrm{C}$ (i.e. digester I) and the main digester was kept at ambient temperature (i.e. digester II). Co-digestion of vegetable waste and cow dung was investigated in two phase anaerobic biodigester system.

A comparative study was carried out between control and experimental system. The amendment was controlled air supply in predigester (digester I) designed to supply with precise control in the experimental system and no aeration was done in the predigester of control system. The conditions of start up and operation were same in both the systems except controlled supply of air.

A conversion of an average of $75 \%$ of organic solids fed into digester at total of 15 days hydraulic retention time (HRT) was obtained for both the system. The organic loading rate in phase I digester was 4-4.5 $\mathrm{kg} \mathrm{VS} / \mathrm{m}^{3} / \mathrm{d}$. This phase effluent portray a drop in the $\mathrm{pH}$ to 4.4-4.7 as high volatile fatty acid produced in the range of 2380-5464 mg/lt with a corresponding gas production of $0.401 \mathrm{~m}^{3} / \mathrm{kg} v \mathrm{v}$. fed in the experimental system, which showed increased biogas yield than the control system.

Due to the auto thermal thermophilic aerobic digestion the VFA production was enhanced which ultimately increased the biogas production by $39.72 \%$, as compared to the control system. The NPK value of the digested sludge obtained was having 0.55\% of Nitrogen, 0.56\% of Phosphorous and $0.61 \%$ of Potash. Thus, limited quantity of oxygen can even lead to improved performance of anaerobic digestion reactor, under certain operating conditions. This fact is also supported by the increase in the viable count of bacteria in the experimental system, It was seen that the aeration in predigester (in two phase anaerobic digestion), could assist anaerobic digestion and would prove much beneficial, for treatment strategy for simultaneous waste treatment and energy generation.
\end{abstract}

Keywords:_Controlled Aeration, Thermophilic digestion, two phase, vegetable waste, volatile fatty acids.

\section{Introduction}

One of the burning problems faced, by the world today is the waste management of the waste produced from all sources. The waste produced in the vegetable market contributes, significantly, as a daily waste producing source. Thus, if this vegetable waste not handled efficiently may cause other hazards to environment. Because of this, government and industries are constantly on the lookout for better technologies, that allows more efficient and cost effective treatment.

An alternative technology that can successfully treat the waste is 'anaerobic digestion' [1]. This process is also effective for the treatment of various organic wastes [2,3]. Various suitable biowastes have been observed for their potential as a supplement to the cattle dung digesters for increasing biogas production. Parthenium (Santa maria Feverfew) weed, which has allergy-causing potential, is a good source of biomass but due to its health hazard it did not receive much public favour [4]. Utilization of agro waste and some specialized organic waste such as, Brassica compestries [5], Soya sludge [6], Jatropha oil meal [7], and Forest residue-waste gum residue [8] have also been used for the biogas enhancement in cattle dung digesters. Addition of tomato plant wastes to rabbit waste in a proportion higher than $40 \%$ improved the methane production [9]. Considering the above studies, use of this technology for the production of biogas using vegetable waste has been reported in the present study.

The first confirmed historical evidences of using biogas is found related to Assyria, where it was used for heating bath water during the $30^{\text {th }}$ century B.C[10]. The first documented engineered anaerobic digester was put into operations in the year 1859 in Mumbai, India [11], using the process for waste treatment and utilizing biogas for lighting. Compared to alternative treatment methods, the merits of anaerobic digestion include low sludge production, high organic loading rates, energy values of methane and low energy consumption $[12,13]$. Anaerobic digesters further contribute to reduce green house gas emission $[14,15,16]$. Generation of nutrient 
rich digestates, which can be used as a fertilizer $[17,18]$ is an added advantage. These merits of anaerobic digestion have let to a rapid growth of its application.

Anaerobic digestion is frighteningly sensitive to changes of operating and feed condition as it's a complex biochemical process $[19,20]$. Lyberatos and Skiadas [21] made a review of early anaerobic digestion models and pointed out that modeling of digester behavior when exposed to an inhibiter (eg. Oxygen) is an area where further attention is necessary. Accidental or unavoidable oxygen loading may pose problem in anaerobic digestion. To cope with this inherent instability, it is essential to develop sufficient control techniques. Hence, an approach towards the process is needed. Anaerobic digestion can also provide benefits from the different means of enhancing process efficiency [22]. This may improve the economy of biogas generation plants enhancing the dissemination of such sustainable solutions. Partial aeration, assisted anaerobic digestion has been recognized as a possible way to enhance anaerobic digestion performance [23-26].

It is quite natural, that some amount of oxygen can reach anaerobic digester unintentionally especially through the interaction with the surrounding while feeding or mixing as the reactors are operated within aerobically open environment. From literature improved hydrolysis of particulate matter in AD is observed in the presence of oxygen $[27,28]$. Since hydrolysis is often the rate limiting reaction stage when the substrate is composed of organic particulate matter [29,30], enhanced hydrolysis can greatly benefit the overall process efficiency. It is commonly known that the hydrolysis rate are significantly higher under aerobic and anoxic conditions compared to anaerobic conditions [31].Botheju et al.[32] demonstrated the possibility of the existence of an optimum oxygenation level which would yield a maximum methane generation in anaerobic digestion. It can be hypothesized that more acidogenic biomass leads to more hydrolysis since hydrolysis is carried out by the extacellular enzymes excreted by acidogens. In the presence of oxygen facultative acidogens can have a higher yield leading to a higher population and more enzymes. Also aerobic conditions favors faster growth of bacteria favoring more acidogenic conditions in the digester Gioannis et al. [33] reported that supplying of additional facultative biomass into the hydrolysis/acidogensis stage of a two phase biogas reactor lead to enhance performance of the acidogenic reactor which then made a clear positive impact on the methanogenic reactor.

On the basis of the literature discussed above it was decided to carry out two phase anaerobic digestion. In which digester I was supposed to be operated under partially thermophilic and aerobic condition and digester II was operated at ambient temperature.

\section{Materials And Methods}

The substrate vegetable waste was collected from a market yard, Pune (India) was used for the experiment. A mixture of vegetable waste slurry was prepared with addition of water to get homogenized mixture, having a solid content of 10 to $16 \%$ approximately.

The inoculum used to seed the reactor was cow dung mixed with water in the ratio of 1:1, in order to get 8 to $10 \%$ total solids. Slurry was passed through a coarse sieve to remove stone and straw to prevent choking of the feed line. The characteristic of the vegetable waste slurry were analysed for physico-chemical parameters as shown in table No.2. Characteristics of seed sludge used in the reactor are given in table No.1

A comparative study was done on the two running system, namely control and experimental. Four digesters were fabricated using still drums. Two digesters out of four had a total volume of $10 \mathrm{~L}$ capacity while the other two were of $15 \mathrm{~L}$. The working volume of the thermophilic digester (phase I) was $6 \mathrm{~L}$ and main digester (phase II) was of 12L which was kept at ambient temperature. Arrangements were made to feed and withdraw the slurry and also to collect the gas generation. The hydraulic retention time (HRT) of the thermophilic digester (phase I) was of 3 days and 12 days for methanogenic digester (phase II). Thus a total hydraulic retention time was of 15days for both control and experimental system. Literature [34] has reported 30 days as optimum hydraulic retention time for single phase digestion but two phase digestion separates the acidogensis and methanogenesis and reduce the hydraulic retention time to half.

Initially all the digesters were filled with seed slurry for energizing the digester and kept for 40 days. After acclimatization regular feeding of the vegetable waste slurry were initiated. Daily 2 liters of the digested slurry was withdrawn and same amount of slurry was fed into the digester I and one liter of the phase I effluent was fed into the phase II digester. After feeding the slurry the digesters were manually mixed frequently for the four to five times in a day.

To maintain thermophilic aerobic condition partial air supply was done in phase I digester of experimental system and control system was with no aeration. Previously we performed experiments with various air flow rates, the microaerobic condition air flow rate of only $0.066 \mathrm{v} / \mathrm{v} / \mathrm{h}$ (volume of air per volume of slurry per hour) gave volatile acid concentration $950 \mathrm{mg} / \mathrm{L}$, the transition condition air flow rate of $0.1 \mathrm{v} / \mathrm{v} / \mathrm{h}$ produced the highest VFA concentration, $2538 \mathrm{mg} / \mathrm{L}$. The aerobic condition, air flow rate $0.133 \mathrm{v} / \mathrm{v} / \mathrm{h}$ showed drop in VFA concentration to, $80 \mathrm{mg} / \mathrm{L}$. Thus we choose the aeration rate $0.05 \mathrm{v} / \mathrm{v} / \mathrm{h}$ (i.e. 0.1 volume of air per hour) after every 30 minutes. The methanogenic digesters (phase II) of both the systems were maintained 
completely anaerobic. As per literature Methanogenic microorganisms (archaea) are categorized as the strictest anaerobes known, with little or no tolerance to oxygen. Hence optimum condition was maintained in phase II digester.

After two turn overs when the gas production was constant the influent and effluent samples were collected regularly and they were subjected to analysis. Routine parameters of prime importance in anaerobic fermentation viz; $\mathrm{pH}$, alkalinity, volatile acid ,total volatile solids, C:N ratio, total solids, total nitrogen total phosphorous, total potash etc. of both raw and digested slurry of both the systems were estimated as per the standard methods (22 ${ }^{\text {nd }}$ edition 2012)[35]. Individual volatile acid concentration was analysed by gas chromatographic (GC) method. GC analyses were performed on the GC/MS/MS, TSQ Quantum instrument method. Gas production was also monitored regularly and gas analysis was carried out. Methane gas was analyzed using Uniphos 399 methane meter and $\mathrm{CO}^{2}$ was analysed by Orsat gas analyser. Percent volatile solid reduction was calculated as per the method described by Van Kleeck formula [36].

\section{Result And Discussion}

The vegetable waste slurry was fed with an average $\mathrm{pH}$ of 7.3. As per the literature $\mathrm{pH}$ in the range of 6.8 to 7.4 should be maintained in the anaerobic digestion process which is the optimum range for methanogens growth [37]. The methanogenic reactor (phase II), residue average $\mathrm{pH}$ was 7.1 and 7 for control and experimental system respectively which is within the optimal $\mathrm{pH}$ range. In an anaerobic system, the Acetogenic bacteria converts' organic matter to organic acids, this possibly decreases the $\mathrm{pH}$ of the reactor. The Total Viable Count in predigester (phase I) of experimental system was $53 * 10^{10} \mathrm{cfu} / \mathrm{ml}$ and that of control system was $11 * 10^{7} \mathrm{cfu} / \mathrm{ml}$ this shows that controlled aeration increased the viable count resulting into rapid acidification of the vegetable waste. The phase I reactor of the experimental system depicts a pH drop up to 4.4 4.7. The $\mathrm{pH}$ of the seed sludge is near neutral 6.8 as shown in table No.1.

Table 1: Characteristics of seed material (cow dung)

\begin{tabular}{|l|l|}
\hline \multicolumn{1}{|c|}{ Parameter } & \multicolumn{1}{c|}{ Values } \\
\hline Seed Sludge & $6.80 \pm 0.1$ \\
\hline $\mathrm{pH}$ & $2040 \pm 120$ \\
\hline Alkalinity,mg l ${ }^{-1}$ & $680 \pm 75$ \\
\hline Volatile acids, $\mathrm{mg} \mathrm{l}^{-1}$ & $20 \pm 3$ \\
\hline $\mathrm{C}: \mathrm{N}$ & $5.05 \pm 2.04$ \\
\hline Total solids, (\%) & $3.00 \pm 1.02$ \\
\hline Total volatile solids, $\%)$ & \\
\hline
\end{tabular}

The average total solids in the feedstock were $17 \%$. The average volatile solids of total solids in the feedstock were $75 \%$. The removal efficiency of volatile solids was in the range of $22.86-26.44 \%$ and 38.32 $40.46 \%$ in control and experimental system respectively with respect to feedstock. The characteristics of feed stock are given in table 2 .

Table 2: Characteristic of feed (Vegetable waste)

\begin{tabular}{|l|l|}
\hline \multicolumn{1}{|c|}{ Parameters } & \multicolumn{1}{|c|}{ Values } \\
\hline $\mathrm{PH}$ & $7.3 \pm 0.1$ \\
\hline Alkalinity, as $\mathrm{CaCO}_{3} \mathrm{mg} \mathrm{l}^{-1}$ & $6200 \pm 140$ \\
\hline Volatile acids, as $\mathrm{CH}_{3} \mathrm{COOH}, \mathrm{mg} \mathrm{l}^{-1}$ & $602 \pm 22$ \\
\hline $\mathrm{C}: \mathrm{N}$ & $22 \pm 2$ \\
\hline Total solids, (\%) & $17.0 \pm 0.15$ \\
\hline Total volatile solids, (\%) & $12.7 \pm 1.4$ \\
\hline \% Volatile solids of total solids & $74.92 \pm 2.93$ \\
\hline
\end{tabular}

A carbon to nitrogen $(\mathrm{C} / \mathrm{N})$ ratio fluctuated due to the heterogeneity of solid substrate and observed marginally decreased through out the study period in control system while in case of experimental system C:N ratio ranges between 22 to 25 seemed to be better for anaerobic co-digestion of vegetable waste. Performance of the control and experimental system receiving the substrate slurry is given in table No. 3 . 
Table 3: Performance of Digester I \& II of control and experimental system

\begin{tabular}{|c|c|c|}
\hline \multicolumn{3}{|c|}{ Performance of Digester I } \\
\hline Parameters & $\begin{array}{c}\text { Control system } \\
\text { (No aeration) }\end{array}$ & Experimental system \\
\hline $\mathrm{PH}$ & $5.7 \pm 0.1$ & $4.5 \pm 0.1$ \\
\hline Alkalinity, as $\mathrm{CaCO}_{3} \mathrm{mg} \mathrm{l}^{-1}$ & $6205 \pm 25$ & $7449 \pm 681$ \\
\hline Volatile acids, as $\mathrm{CH}_{3} \mathrm{COOH}, \mathrm{mg} \mathrm{l}^{-1}$ & $2150 \pm 1190$ & $3922 \pm 1542$ \\
\hline $\mathrm{C}: \mathrm{N}$ & $21 \pm 1$ & $23 \pm 1$ \\
\hline Total solids, $(\%)$ & $12.8 \pm 0.17$ & $12.0 \pm 0.15$ \\
\hline Total volatile solids, $(\%)$ & $9.96 \pm 0.36$ & $9.25 \pm 0.13$ \\
\hline \multicolumn{3}{|c|}{ Performance of Digester II } \\
\hline Parameters & Control system & Experimental system \\
\hline $\mathrm{pH}$ & $7.1 \pm 0.1$ & $7 \pm 0.1$ \\
\hline Alkalinity, $\mathrm{mg} \mathrm{l}^{-1}$ & $4600 \pm 60$ & $4782 \pm 82$ \\
\hline Volatile acids, $\mathrm{mg} \mathrm{l}^{-1}$ & $488 \pm 104$ & $590 \pm 100$ \\
\hline $\mathrm{C}: \mathrm{N}$ & $19 \pm 2$ & $23 \pm 2$ \\
\hline Total solids, $(\%)$ & $10.8 \pm 0.3$ & $10.4 \pm 0.11$ \\
\hline Total volatile solids, $(\%)$ & $7.51 \pm 0.51$ & $7.21 \pm 0.23$ \\
\hline
\end{tabular}

Table No. 4 indicates individual volatile acid concentration in control and experimental system during acidogensis of vegetable waste slurry in phase I reactor.

Table 4: Volatile fatty acid concentration (Digester I)

\begin{tabular}{|l|l|l|}
\hline \multicolumn{1}{|c|}{ VFA concentration } & \multicolumn{1}{|c|}{ Control System } & \multicolumn{1}{|c|}{ Experimental System } \\
\hline Acetic acid \% & 63.96 & 75.60 \\
\hline Formic acid \% & NF & NF \\
\hline Propionic acid \% & 20.74 & 14.26 \\
\hline Buteric acid \% & 14.98 & 10.14 \\
\hline
\end{tabular}

The percent volatile solid reduction with the corresponding gas production is mentioned in table 5 . The manurial value of the experimental system is less than the control system but it is within the range of the concentration of farm yard manure. (Source of the farm yard manure concentration: Overcash et al.1983)

Table 5: Percentage of the biochemical parameters of the effluent with respect to feed stocks and biogas production in both the system

\begin{tabular}{|l|l|l|}
\hline Parameters & Control System & Experimental System \\
\hline VS reduction, \% & $22.86 \%-26.44 \%$ & $38.32 \%-40.46 \%$ \\
\hline Biogas Production, (m3/kg VS feed) & $0.283-0.291$ & $0.394-0.405$ \\
\hline Methane content, \% & $60 \%-63 \%$ & $63 \%-68 \%$ \\
\hline CO2 Content\% & $37 \%-40 \%$ & $34 \%-37 \%$ \\
\hline Plant Nutrient content: & $0.56 \pm 0.03$ & $0.55 \pm 0.12$ \\
\hline Nitrogen, \% & $0.54 \pm 0.05$ & $0.56 \pm 0.04$ \\
\hline Phosphorus, \% & $0.63 \pm 0.10$ & $0.61 \pm 0.15$ \\
\hline Potash, \% &
\end{tabular}

Volatile acids are necessary intermediates of sludge stabilization. It is reported that VFA/Alkalinity ratio should be less than 0.4 for the reactor to be stable [38]. This ratio ranged between $0.10-0.15$ i.e. maintained below 0.2 in main digester (phase II) for both control and experimental system. Thus the reactor was completely stable and steady through out the study period by balancing the consumption of volatile acid which are produced in the phase I (acidogenic) reactor. The VFA/Alkalinity ratio in the reactor is shown in figure 1. 


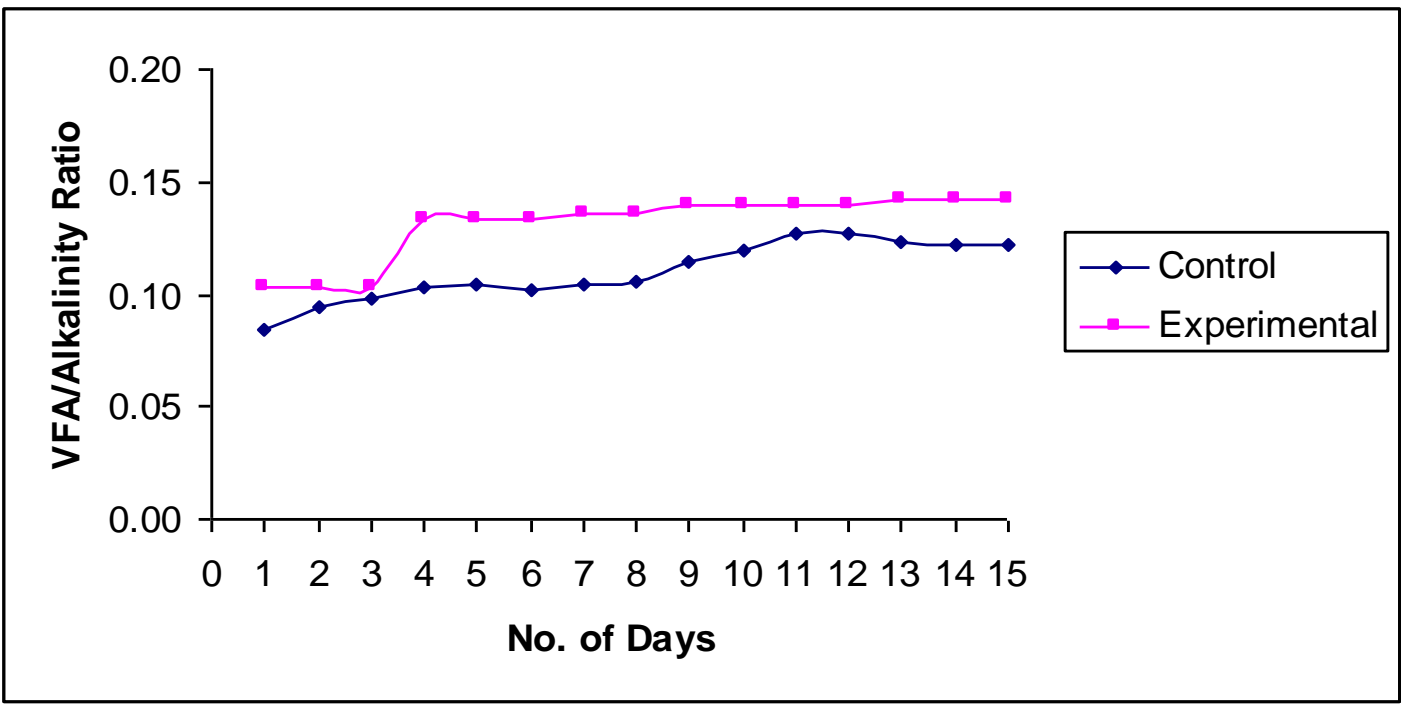

Figure 1. VFA / Alkalinity ratio in the methanogenic reactor (Phase II)

The average gas production in the control and experimental system (II ${ }^{\text {nd }}$ Phase) maintained for 12 days is shown in table No.6.

Table 6: Gas production in control and experimental system.

\begin{tabular}{|c|c|c|}
\hline \multicolumn{1}{|c|}{ the. of Days. } & Control System & Experimental System. \\
\cline { 2 - 4 } & $\begin{array}{c}\text { Gas in } \\
(\mathrm{m} 3 / \mathrm{kg} \text { VS feed })\end{array}$ & $\begin{array}{c}\text { Gas in } \\
\text { (m3/kg VS feed) }\end{array}$ \\
\hline 1 & 0.291 & 0.394 \\
\hline 2 & 0.286 & 0.402 \\
\hline 3 & 0.288 & 0.400 \\
\hline 4 & 0.283 & 0.399 \\
\hline 5 & 0.285 & 0.402 \\
\hline 6 & 0.287 & 0.405 \\
\hline 7 & 0.288 & 0.405 \\
\hline 8 & 0.289 & 0.404 \\
\hline 9 & 0.290 & 0.401 \\
\hline 10 & 0.285 & 0.400 \\
\hline 11 & 0.283 & 0.402 \\
\hline 12 & 0.284 & 0.403 \\
\hline 13 & 0.285 & 0.400 \\
\hline 14 & 0.289 & 0.401 \\
\hline 15 & 0.286 & 0.402 \\
\hline Average & $\mathbf{0 . 2 8 7}$ & $\mathbf{0 . 4 0 1}$ \\
\hline increase in gas with respect to control & $\mathbf{3 9 . 7 2 \%}$ \\
\hline
\end{tabular}

readings are the average of ten days)

The average biogas production ranged from $0.283-0.291$ and $0.394-0.405 \mathrm{~m} 3 / \mathrm{kg}$ VS added in control and experimental system respectively. The methane rich gas having upto $66 \%$ of methane content produced in phase II digester by biomethanation of mixture of vegetable waste. The gas production observed during the study period is shown in (Fig. 2.) 


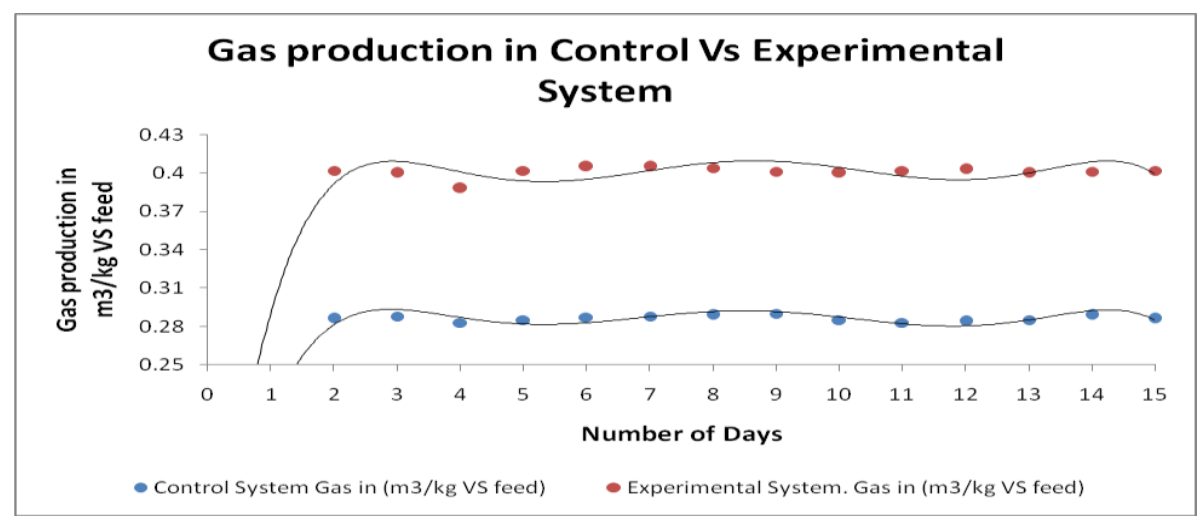

Figure2. Comparative Gas production of Control System Vs Experimental System

\section{Conclusion}

The results suggest that to face the challenge of hydrolysis during anaerobic digestion of particulate substrate like vegetable waste can be improved by micro aeration it can be inferred that aeration in predigester (phase I) can enhance the hydrolysis and even the acidogensis stage of anaerobic digestion may be due to faster growth of bacterial population or consortia . It is also revealed that in phase separated digestion system, partial aeration in predigester (phase1) can most suitably be incorporated with the initial hydrolysis stage.

Limited aeration can be used as a pretreatment prior to anaerobic digestion to enhance the digestibility of different types of waste resulting in to generation of additional volatile fatty acid by increased activity of acidogens. The amendment of air to the experimental system helped to enhance gas production and volatile solid reduction. This will help in disposal of the waste very soon without causing storage problems.

It is suggested that partial aeration assisted anaerobic digestion can became a useful waste treatment and a renewable energy generation scheme with multiple benefits.

\section{References}

[1]. B. Koumanova, M. Saev, Anaerobic digestion of waste fruits and vegetables (Review), Ecological Engineering and Environmental protection, 1,2008,20-29.

[2]. I. Simeonov,S.Mihajlova,A.Mirkov,Y.Petkov,E.Chorukova,Biogas production from organic wastes in laboratory digesters, Ecological Engineering and Environmental Protection,2,2007,23-32.

[3]. L.Nikolov, I.Simenonv,D. Karakashev,E.Chorukova,D.Galabova,Anaerobic digestion of complex mixture of organic waste, Ecological Engineering and Environmental Protection,3,2004,42-52.

[4]. Banerjee AK. Biogas from Parthenium, Article published in The Times of India, 1987.

[5]. Shanta Satyanarayan, Paresh Murkute, Ramakant. Biogas production enhancement by Brassica compestries amendment in cattle dung digester, Biomass and Bioenergy, 30, 2008,210 - 215.

[6]. Shanta Satyanarayan, Ramakant and shivayogi, Biogas production enhancement by soya sludge amendment in cattle dung digesters. Biomass and Bioenergy, 34: 2010, 1278-1282.

[7]. Pal, S.L. and Shanta Satyanarayan, Enhancement of biogas production by Jatropha cureus amendment in cattle dung digesters. International Conference on RDEIA-IACM, NEERI, March 2012, 28-30.

[8]. Shanta Satyanarayan and Nikesh Banwade, Enhancement of biogas by Forest Residue amendment in cattle dung digesters. Ph.D. Thesis, 2012, Nagpur University.

[9]. Trujillo D, Perez JF, Cerebros FJ.Energy recovery from waste: anaerobic digestion of tomato mixed with rabbit waste, Bioresource Technology 1993; 45(2):81-3.

[10]. S. Verma, "Anaerobic digestion of biodegradable organics in Municipal solid wastes", M.Sc. thesis, Columbia University, 2002.

[11]. F. Monnet, "An introduction to anaerobic digestion of organic wastes", Final Report by Remade Scotland Initiative, 2003.Available online: http://www.biogasmax.eu/media/introanaerobicdigestion $073323000 \quad 1011$ 24042007.pdf

[12]. G. Tchobanoglous, F. L. Burton, and H. D. Stensel, Meltcalf \& Eddy, Inc.'s Wastewater Engineering: Treatment, Disposal, and Reuse. Tata McGraw-Hill publishing company Ltd, 4th Edition, 2003.

[13]. K. Braber, "Anaerobic digestion of municipal solid waste; A modern waste disposal option on the verge of breakthrough", Biomass and Bioenergy, vol. 9 (1 - 5), pp. 365-376, 1995.

[14]. L. Yu, K. Yaoqiu, H. Ningsheng, W. Zhifeng, and X. Lianzhong,"Popularizing household-scale biogas digesters for rural sustainable energy development and greenhouse gas mitigation”, Renewable Energy, vol. 33, pp. 2027-2035, 2008.

[15]. M. Lantz, M. Svensson, L. Björnsson, and P. Börjesson, "The prospects for an expansion of biogas systems in Sweden -Incentives, barriers and potentials", Energy Policy, vol. 35, pp.1830-1843, 2007.

[16]. J. B. H. Nielsen, T. A. Seadi, and P. O. Popiel, "The future of anaerobic digestion and biogas utilization", Bioresource Technology, vol. 100, pp. 5478-5484, 2009.

[17]. M. Berglund, and P. Börjesson, "Assessment of energy performance in the life-cycle of biogas production", Biomass and Bioenergy, vol. 30, pp. 254-266, 2006.

[18]. D. Botheju, Ø. Svalheim, B. Rydtun, J. Johansen, T. K. Haraldsen, and R. Bakke, "Fertilizer production by digestate nitrification", in proceedings of the 12th European Biosolids and Organic Resources Conference, Manchester, UK, November 2007.

[19]. L. Krause, N. N. Diaz, R. A. Edwardse, K-H. Gartemann, H. Krömeke, H. Neuweger, A. Pühler, K. J. Runte, A. Schlüter, J. Stoye, R. Szczepanowski, A. Tauch, and A. Goesmann, "Taxonomic composition and gene content of a methane-producing microbial community isolated from a biogas reactor", Journal of Biotechnology, vol. 136, pp. 91-101, 2008. 
[20]. H. N. Gavala, U. Yenal, I. V. Skiadas, P. Westermann, and B. K. Ahring, "Mesophilic and thermophilic anaerobic digestion of primary and secondary sludge: Effect of pre-treatment at elevated temperature", Water Research, vol. 37, pp. 4561-4572, 2003.

[21]. G. Lyberatos and I. V. Skiadas, "Modeling of anaerobic digestion -a review", Global Nest: The International Journal, vol. 1 (2), pp.63-76, 1999.

[22]. P. Kaparaju, L. Ellegaard, and I. Angelidaki, "Optimisation of biogas production from manure through serial digestion: Lab-scale and pilot-scale studies", Bioresource Technology, vol. 100, pp.701-709, 2009.

[23]. D. Botheju, G. Samarakoon, C. Chen, and R. Bakke, "An experimental study on the effects of oxygen in bio-gasification; Part 1", in proceedings of the International Conference on Renewable Energies and Power Quality (ICREPQ 10), Granada,Spain, March, 2010. Archived in Renewable Energies \&Power Quality Journal (RE\&PQJ), vol. 8, 2010d.

[24]. D. Botheju, G. Samarakoon, C. Chen, and R. Bakke, “An experimental study on the effects of oxygen in bio-gasification; Part 2", in proceedings of the International Conference on Renewable Energies and Power Quality (ICREPQ 10), Granada,Spain, March, 2010. Archived in Renewable Energies \&Power Quality Journal (RE\&PQJ), vol. 8, 2010e.

[25]. M. F. Polanco, I. Diaz, S. I. Pérez, A. C. Lopes, and F. F. Polanco, "Hydrogen sulphide removal in the anaerobic digestion of sludge by micro-aerobic processes: Pilot plant experience”, Water Science and Technology, vol. 60, no. 12, pp. 3045-3050, 2009a

[26]. P. G. Rathnasiri, "Anaerobic digestion process using membrane integrated micro-aeration", PhD Thesis, Norwegian University of Science and Technology (NTNU), 2009.

[27]. L. Hao, P. J. He, F. Lu, L. Shao, and M. Zhu, "Regulating the hydrolysis of organic waste by micro-aeration and effluent recirculation", Waste Management, vol. 29, pp. 2042-2050, 2009.

[28]. P. S. Jagadabhi, P. Kaparaju, and J. Rintala, "Effect of microaeration and leachate replacement on COD solubilization and VFA production during mono-digestion of grass-silage in one-stage leach-bed reactors", Bioresource Technology, vol. 101, pp. 2818$2824,2009$.

[29]. M. Myint, N. Nirmalakhandan, and R. E. Speece, "Anaerobic fermentation of cattle manure: Modeling of hydrolysis and acidogensis", Water Research, vol. 41, pp. 323-332, 2007.

[30]. M. Climent, I. Ferrer, M. d. M. Baeza, A. Artola, F. V'azquez, and X. Font, "Effects of thermal and mechanical pretreatments of secondary sludge on biogas production under thermophilic conditions", Chemical Engineering Journal, vol. 133, pp. 335$342,2007$.

[31]. M. Henze, W. Gujer, T. Mino, T. Matsuo, M. C. Wentzel, and G. V. R. Marais, Activated sludge model no. 2; IAWQ Scientific and Technical Report no. 3, London: IAWQ, 1995.

[32]. D. Botheju, B. Lie, and R. Bakke, "Oxygen effects in Anaerobic Digestion - II", Modeling, Identification and Control, vol. 31, no.2, pp. 55-65, 2010 f.

[33]. G. D. Gioannis, L. F. Diaz, A. Muntoni, and A. Pisanu, "Two phase anaerobic digestion within a solid waste/wastewater integrated management system", Waste Management, vol. 28, pp.1801-1808, 2008.

[34]. Satyanarayan S. Performance of lab digesters receiving mixed feed of cattle dung and night soil National Environmental Engineering Research Institute (NEERI) internal report, Nagpur, India 1977.

[35]. Standard methods for the examination of water and wastewater 2012, 22nd edition APHA, AWWA AND WPCF.

[36]. Anaerobic Sludge Digestion 1999, MOP volume 16.

[37]. Sharma V K, Testa C, Cornacchia G, Lastella G and Farina R, "Anaerobic digestion of semi-solid organic waste available from orthofruit market: Preliminary experimental results", Energy Conversion and Management, 1999, 40: 287-304.

[38]. Callaghan F J, Wase D A J, Thayanithy K and Forster C F, "Continuous co- digestion of cattle slurry with fruit and vegetable wastes and chicken manure", Biomass and Bioenergy, 2002, 27: 71-77. 